\title{
TELAAH PRAKTIK HIJABISASI DI LINGKUNGAN UIN SUNAN KALIJAGA (PERSPEKTIF SOSIOLOGI)
}

\author{
Haerul Ahyar \\ UIN Sunan Kalijaga Yogyakarta \\ e-mail : chaerulakhyar75@gmail.com
}

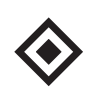

\begin{abstract}
ABSTRAK
Studi tentang pakaian wanita (cadar) atau penulis menyebutnya "hijabisasi" adalah salah satu isu gender yang selalu hangat dan menarik untuk didiskusikan dan bahkan dipelajari oleh para ulama. Dalam tulisan ini, penulis akan mencoba memotret dan melukiskan praktik "hijabisasi" yang terjadi di Universitas Islam Negeri Sunan Kalijaga Yogyakarta dalam perspektif sosiologi. Studi tentang "hijabisasi" dalam tulisan ini termasuk dalam kategori penelitian kualitatif. Penulis mengambil data dari berbagai literatur buku yang membahas tentang pakaian serta melakukan wawancara dengan beberapa orang yang yang terlibat dalam praktik "hijabisasi" di Universitas Islam Negeri sebagai data tambahan di Lapangan. Kesimpulan dari studi penulis dalam penelitian ini diperoleh data bahwa "hijabisasi" sudah ada dan dipraktekkan oleh wanita sebelumnya sebelum Islam terungkap. "Hijabisasi" adalah bagian dari budaya. Sedangkan untuk konteks saat ini, berdasarkan pernyataan wawancaranya apakah praktik "hijabisasi" adalah cara lain yang lebih preventif untuk mencegah gangguan alam dan sosialnya, serta menghias kepribadiannya dan memberikan kepercayaan diri serta rasa nyaman.
\end{abstract}

Kata Kunci: Hijabisasi, UIN Sunan Kalijaga, perspektif sosiologi

\section{PENDAHULUAN}

Beberapa waktu yang lalu, di kalangan civitas akademik UIN Sunan Kalijaga ramai berita tentang larangan berpakaian ala Arab serba tertutup - 
kami menyebutnya 'hijabisasi'- dilingkungan kampus UIN Sunan Kalijaga. Hal tersebut mendadak menjadi soratan dan cibiran beberapa kalangan akademisi dan aktivis kemahasiswaan. Terlebih pernyataan tersebut disampaikan oleh salah satu Wakil Rektor UIN Sunan Kalijaga. ${ }^{1}$ Namun permasalahan tersebut tidaklah berlarut-larut, setelah adanya klarifikasi langsung akhirnya nyala apipun tidak sampai ke permuakaan. Meskipun demikian, hal tersebut terkesan seperti pernyataan sepihak, sehingga menjadi stigma negatif bagi beberapa kalangan yang memandangnya yang seolah-olah membatasi gerak mahasiswa dalam berekspresi.

Adanya pernyataanyang tidaksedap sepertiitu,sampai detikini dilingkungan UIN Sunan Kalijga yang notabennya mahasiswa muslim - muslimah masih saja ada bahkan sekarnag menjadi suatu komunitas eksklusif yang berbusana hijabi (serba tertutup dengan model dan warna yang identik), dengan segala pernakpernik kegiatannya. Jika dilihat dari sudut pandang normatif, praktik hijabisasi menjadi isu gender yang pernah menjadi kajian tafsir kontemporer oleh beberapa tokoh kajian keIslaman seperti Fazlur Rahman ${ }^{2}$ (Indonesia-Pakistan) India dan Muhammad Syahrur ${ }^{3}$ (Timur Tengah) Syuriah. Dimana konsep hijabisasi (jilbab) atau purdah (cadar) menurut Rahman perlunya melihat ayat tentang jilbab tersebut dalam ranah ideal moralnya dari pada legal formalnya. Dimana dimensi ideal moralnya adalah bahwa seorang perempuan harus bersikap sopan, bersahaja dan memakai pakaian yang memenuhi standar kesopanan, meski tidak harus menutup rambutnya apalagi mukanya dengan cadar. ${ }^{4}$ Sedangkan Syahrur dalam menafsirkan buasan perempuan (libas al-mar'ah) menggunakan pendekatan teori hudûd, berpendapat bahwa ayat jilbab ini bukan merupakan tasyri (penetapan hukum), yang terkait halal-haram, melainkan sekedar ayat ta'lim (ajaran), dimana beliau menafsirkan ayat tentang jilbab dalam batas minimal, sebagai pakaian luar perempuan yang dapat menutup aurat besarnya (satr al-juyub), meliputi farji, pantat, dubur dan dada, seperti dalam (QS. An-Nur [24]: 31), maka dirasa cukup dengan hanya memakai (CD dan BH), sedang dalam

1 http://nusantara.rmol.co/read/2017/10/12/310691/UIN-Kalijaga-Larang-PengenaanPakaian-Ala-Arab-di-Kampus-. Diakses pada tanggal 2 November 2017

2 Lihat buku Abdul Mustaqim, Epistemologi Tafsir Kontemporer, (Yogyakarta: Lkis, 2010), hlm. 269-272

3 Lihat Muhammad Syahrur, Hahwa Ushûl Jadîdah Li al-Fiqhi Al-Islâmi: Fiqh al-Mar'ah, alWashiyyah, al-Irts, al-Qiwâmah, at-Ta'addudiyyah, al-Libas, (Damaskus: al-Ahli li ath-Thiba'ah wa an-Nasyr wa at-Tauzî, 2000). Lihat juga pada Abdul Mustaqim, Epistemologi Tafsir Kontemporer, (Yogyakarta: Lkis, 2010).

$4 \quad$ Lihat Mustaqim, Epistemologi..., hlm. 272 
batas maksimalnya sebagai pakaian yang menutupi seluruh tubuhnya, kecuali wajah dan dua telapak tangan. ${ }^{5}$ Dari kedua tafsir kontemporer di atas, tampak jelas memandang jilbab bukan sebagai pakaian perempuan yang serba tertutup selain kedua telapak tangan dan wajahnya atau pakaian yang dapat menutup aurat menurut rasa kepantasan dan memenuhi standar kesopanan. Meskipun kedua penafsiran di atas terlihat liberal.

Berangkat dari perspektif normatif di atas, maka sedikit lebihnya ada gambaran tentang berbusana hijabi ini. Lantas bagaimana praktik hijabisasi yang masih terlihat di lingkungan UIN Sunan Kalijaga, jika dilihat dengan perspektif sosiologi. Terlebih bagaimana dengan kondisi sosial masyarakat islam kaitannya dalam berbusana pada saat sebelum dan sesudah turunnya wahyu menutup aurat. Bagaimana dengan kondisi kita (Indonesia), yang berbeda dengan kondisi awal turunnya wahyu tersebut dan apakah masih relevan sehingga menjadi keharusan bagi setiap kaum feminim untuk berbusana hijabi. Hal seperti ini perlu kiranya kita respon dengan baik dan tepat sehingga tidak terjadi kesalah pahaman yang tidak diinginkan seperti mengkafir-kafirkan sesama umat muslim, bahkan mengjustifikasi anggota radikal, yang pada akhirnya menjadi stereotif negatif dikhalayak umum.

Dari pemaparan di atas, makalah ini mencoba memotret serta menelaah bagaimana praktik menutup aurat (hijabisasi) tersebut dengan menggunakan pendekatan sosiologi, artinya pendekatan ini ingin melihat interelasi antara Agama dan sosial masyarakat, dalam hal ini bagaimana hubungan sosial para pemakai hijabi dilingkungan UIN itu sendiri dan umumnya kondisi masyarakat Islam dalam berbusana. Apakah ada tendensi Agama (Islam) yang mengatur cara berpakaian hijabi tersebut atau ada faktor lain sehingga mahasiswa UIN masih ada yang berbusana hijabi meski sudah ada pernyataan larangan. Denganperspektif sosiologi ini diharap dapat memberikan kejelasan motif yang melatarbelakangi praktik hijabisasi yang dilakukan oleh sebagian mahasiswi UIN Sunan Kalijaga itu sendiri.

\section{KERANGKA TEORI}

Dari beberapa variabel dalam makalah ini, perlu kiranya dijelaskan terlebih dahulu variabel-variabel tersebutagar pembahasan dalam makalah

5 Lihat Muhammad Syahrur, Nahwa Usûl Jadîdah..., hlm. 364. Lihat pula Syahrur, Al-Kitab Wa AlQur'ân, hlm. 615. Sebagaimana dikutip Mustaqim, Epistemologi ..., hlm. 272 
ini mempunyai dasar yang kuat dan kokoh. Bermula dari definisi pendekatan, secara bahasa pendekatan adalah proses, cara, perbuatan mendekati (hendak bersahabat, dan sebagainya. ${ }^{6}$ Sedangkan dalam ranah kajian keislaman, pendekatan dimana menurut hemat penulis ialah suatu cara mendekati sesuatu, atau cara pandang yang digunakan dalam mendekati suatu masalah guna mendapatkan pemahaman tersendiri. Sedangkan istilah Sosiologi berasal dari bahasa Latin "socio" yang berarti 'masyarakat' dan bahasa Yunani "logy" atau "logos" yang berarti 'ilmu'. Dari dua istilah tersebut, maka arti keseluruhan sosiologi adalah 'ilmu yang mempelajari tentang masyarakat'. Dalam arti yang lebih luas sosiologi merupakan studi sistematik terhadap masyarakat manusia dengan menekankan pada kelompok sosial beserta konsekuensi dari kehidupan bersama. ${ }^{8}$ Selain definisi di atas, masih banyak definisi lain tentang sosiologi yang dikemukakan oleh para ahli. Namun demikian, pada umumnya sosiologi dikenal sebagai ilmu pengetahuan tentang masyarakat yang hendak mempelajari masyarakat, perilaku masyarakat dan perilaku sosial masyarakat dengan cara mengamati perilaku kelompok yang dibangunnya. Dari definisi kedua istilah tersebut, maka dapat ditarik suatu kesimpulan bahwa pendekatan sosiologi merupakan cara pandang digunakan dalam mendekati suatu masalah dengan melihat langsung interaksi sosial masyarakat yang berlaku beserta konsekuensi dari kehidupan sosial tersebut.

Salah satu interaksi sosial masyarakat adalah interaksi keagamaan, dimana Agama (Islam) merupakan aspek yang paling penting dalam kehidupan manusia. Kemudian dalam rangka memahami dinamika keagamaan, sosiologi dapat dijadikan salah satu suatu pendekatan yang signifikan, melihat banyaknya ajaran Agama yang berkaitan dengan masalah sosial. Besarnya perhatian Agama terhadap masalah sosial ini, yang selanjutnya mendorong agamawan memahami ilmu-ilmu sosial sebagai alat memahami Agamanya. Maka dari itu dengan pendekatan sosiologi, Agama dapat dipahami dengan mudah, karena Agama itu sendiri diturunkan untuk kepentingan sosial. Dalam al-Qur'an misalnya dijumpai ayat-ayat berkenaan dengan hubungan antara sesama manusia (hablun min annas), sebab-sebab yang menyebabkan terjadinya kemakmuran suatu bangsa dan sebab-sebab yang menyebabkan terjadinya kesengsaraan. Semua itu hanya baru

6 Tim Penyusun Kamus Besar Bahasa Indonesia, Kamus Besar Bahasa Indonesia, cet.2, (Jakarta: Balai pustaka, 1989), hlm.

7 Sindung Haryanto, Sosiologi Agama: Dari Klasik Hingga Postmodern, (Yogyakarta: Ar-Ruzz Media, 2016), hlm. 55.

8 Ibid..., hlm. 13 
dapat dijelaskan apabila yang memahaminya mengetahui sejarah sosial pada ajaran Agama itu diturunkan. ${ }^{9}$

Istilah hijabisasi diambil kata hijab yang secara leksikal berarti penutup, pengahalang atau tirai. Dalam Kamus Besar Bahasa Indonesia (KBBI) kata hijab berarti dinding yang membatasi sesuatu dengan yang lain, pembatas, penyekat yang membatasi hati manusia dengan Allah. ${ }^{10}$ Menurut Syahrur, Kata hijab dalam penggunaannya tidak pernah dikaitkan dengan masalah pakaian (al-libâs), meski kata hijab disebut sebanyak delapan kali dalam at-Tanzil alHakim. ${ }^{11}$ Namun melihat trend dimasyarakat, dewasa ini kata hijab menjadi istilah yang digunakan untuk menunjukan cara berbusana perempuan (libas al-mar'ah) yang sering dipakai atau disebut sebagai pakaian syar'i (hijâb asySyarî́).$^{12}$ Bahkan akhir-akhir ini menjadi busana hijabi sering di kaitkan dengan cara berbusana secara tertutup seluruh badannya, selain pandangan mata dan telapak tangannya, secara eksplisitnya adalah seperangkat assesoris busana jilbab dan purdah (cadar), bahkan memliki warna yang identik.

Secara normatif, Al-Quran memaparkan masalah seperangkat pakaian perempuan (libasal-mar'ah), yaitu;penutup (hijâb), jilbab dan kerudung (khimâr) dalam tiga ayat saja. Pertama adalah ayat tentang hijab yang secara terbatas terkait dengan para isteri Nabi (Qs. Al-Ahzab [33]: 53), ayat kedua adalah ayat tentang jilbab yang ditunjukan kepada isteri Rasul dan isteri orang-orang beriman, yakni dalam (Qs. Al-Ahzab [33]: 59), dan ketiga ayat yang terkait dengan masalah tutup kepala perempuan (al-khimar) dan perhiasan yang ditujukan secara umum bagi seluruh perempuan beriman, yang termaktub dalam (Qs. An-Nur [24]: 31). ${ }^{13}$

Berbusana merupakan cara menampilkan keindahan yang tercermin pada diri pribadi seseorang dengan senan tiasa memperhatikanetika dan estetika dalam kelompoknya. Sudah menjadi hal yang mainstream ketika praktik berbusana dikaitkan dengan sosok perempuan, karena hal tersebut merupakan salah satu cara menghiasi dan memperindah dari dari sisi luarnya

\footnotetext{
Abuddin Nata, Metodelogi Studi Islam, (Jakarta : RajaGrafindo Persada, 2002), hlm. 42.

10 Tim Penyusun Kamus Besar Bahasa Indonesia, Kamus Besar Bahasa Indonesia, cet.2, (Jakarta: Balai pustaka, 1989), hlm. 307

11 Muhammad Shahrur dalam Nahwu Usul Jadidah Li al-Fiqih al-Islami: Fiqih al-Mar'ah,al-Wasiat, al-Irts, al-Qiwâmah, at-Ta'addiyah, al-Washiyyah, al-Libâs, (Damaskus: al-Ahali li ath-Thiba'ah wa an-Nasyr wa at-Tauzi', 2000), hlm. 331

12 Lihat Murtadha Muthahhari, On The Islamic Hijab (Hijab: Gaya Hidup Wanita Islam), diterjemahkan oleh Agus Efendi dan Alwiyah Abdurrahman, , cet. V (Bandung: Mizan, 1994), hlm. 11. Lihat juga, Syahrur, Nahwa.., hlm. 331.

13 Lihat Husein al-Audât, al-Mar'ah al-'Arabiyah fi ad-Dîn wa al-Mujtama, sebagaimana dikutip Muhammad Shahrur dalam Nahwu Usul Jadidah Li al-Fiqih al-Islami.., hlm.346
} 
atau disebut ounner beauty, disamping sebagai langkah menutupi auratnya karena fitrah dan melindunginya dari berbagai gangguan, baik yang bersifat alamiyah seperti perubahan cuaca debu dan yang lainnya maupun yang sifatnya sosial, seperti diremehkan dan pelecehan. ${ }^{14}$ Sama halnya menurut Mustaqim bahwa tujuan pokok berpakaian dalam Al-Quran adalah, pertama, sebagai proteksi atau perlindungan, sebagaimana dalam (QS. Al-Ahzab [33]: 59). Kedua, sebagai dekorasi atau 'hiasan diri' penulis menyebutnya dengan ouner beauty sebagamana firman Allah dalam (QS. An-Nur [24]: 31). ${ }^{15}$

Meski secara normatif, sudah dipaparkan dengan jelas namun perlu kiranya kita dekati wajah Islam seperti itu dengan menggunakan pendekatan sosiologi. Oleh karena itu perlu kita ketahui lebih dalam terkait dengan prektek hijabisasi ini, khusunya di lingkungan kampus UIN Sunan Kalijaga, apakah praktikhijabisasi tersebut benar-benar atas dasar tuntutan Agama yang mempengaruhi cara berbusananya atau hanya budaya sosial tertentu yang menjadikannya berbusana seperti itu.

\section{METODE PENELITIAN}

Dalam kaitannya studi Agama (Islam) sebagai gejala sosial maka ruang lingkup kajiannya adalah bagaimana interaksi antara sesama Agana Islam atau interaksi dengan agama lain; dalam hal ini ada yang menggunakan dan/ atau tidak menggunakan norma-norma Islam, serta bagaimana karakteristik interaksi dalam memahami dan mengekspresikan nilai-nilai Islam antara pemeluk agama-agama yang berbeda. ${ }^{16}$ Dalam displin ilmu sosiologi Agama, terdapat berbagai logika teoritis (pendekatan) yang dikembangkan sebagai perspektif utama sosiologi yang seringkali digunakan sebagai landasan dalam melihat fenomena keagamaan di masyarakat. Di antara pendekatan itu yaitu: perspektif fungsionalis, pertukaran, interaksionisme simbolik, konflik, teori penyadaran dan ketergantungan. Masing-masing perspektif itu memiliki karakteristik

\footnotetext{
14 Abdul Wahhab Abdussalam Thawilah, Panduan Berbusana Islami: Berpenampilan Sesuai Tuntunan al-Qur'ân dan as-Sunnah, (Kairo: Dar as-Salam, 2006), hlm. 3-4. Sebagaimana firman Allah (QS. Al-A'raf [7]: 26) yang artinya: "Hai anak Adam, sungguh kami telah menyediakan pakaian untuk menutupi auratmu dan untuk perhiasan bagimu. Namun, pakaian takwa itulah yang paling baik. Demikianlah sebagian dari tanda-tanda kekuasaan Allah, mudah-mudahan mereka selalu ingat".

15 Abdul Mustaqim, Epistemologi..., hlm. 281

16 Atho Mudzhar, Pendekatan Studi Islam: Dalam teori dan Praktik, (Yogyakarta: Pustaka Pelajar, 2011), hlm. 18.
} 
sendiri-sendiri bahkan bisa jadi penggunaan perspektif yang berbeda dalam melihat suatu fenomena keagamaan akan menghasilkan suatu hasil yang saling bertentangan. ${ }^{17}$

Maka dari itu, pendekatan yang akan digunankan dalam mengkaji praktik hijabisasi ini adalah menggunakan pendekatan sosiologi yang bertumpu pada konsep sosiologi Agama yang bertujuan untuk mengetahui dan memahami hubungan interelasi antara Agama dan masyarakat, bagaimana Agama mempengaruhi masyarakat dan sebaliknya bagaimana masyarakat mempengaruhi konsep Agama.Dalam pendekatan sosiologi, Agama dapat berposisi sebagai independent variabel maupun dependent variabel. Ketika Agama sebagai independent variabel maka Agama (Islam) mempengaruhi unsur lain, Sedangkan ketika Agama sebagai dependent variabel berarti Agama (Islam) dipengaruhi faktor lain. ${ }^{18}$

Adapun sumber dan teknik yang digunakan dalam mencari data yang bersifat teoritik dalam studi ini adalah menggunakan beberapa literatur, seperti buku-buku yang membahas perempuan dan pakaian perempuan. Sedangkan data yang bersifat personal-praktis dalam praktik hijabisasi maka digunakan teknik wawancara terhadap beberapa responden.

\section{PEMBAHASAN}

\section{Maksud Hijabisasi}

Sebelum kita memulai pembahasan lebih lanjut, terebih dahulu perlu kiranya kami singgung satu point penting untuk melihat makna dari kata hijabisasi sekalipun pembahasan makna hijabisasi telah disinggung dalam kerangka teori, namun tidak menjadi masalah untuk menjelaskannya kembali dalam sub pembahasan. Dimana hijabisasi dewasa ini menunjukan arti pakaian yang serba tertutup yang dikenakan oleh seorang perempuan. Hal ini sama dengan makna aslinya yaitu tirai atau dinding dalam penggunaannya digunakan untuk penutup yaitu yang melindungi sesuatu dari sesuatu dan mengahalangi antara keduanya. ${ }^{19}$

17 Ahmad Isybah Nurhikam, Pendekatan Sosiologis Dalam Studi Islam, dalam http:// satriabajahikam.blogspot.co.id/2012/02/pendekatan-sosiologis-dalam-studi-islam.html. Diakses pada hari jum'at 29/12/2017

18 Elizabeth K. Nottingham, Agama dan Masyarakat: Suatu Pengantar Sosiologi Agama, Cet.8 (Jakarta: PT. Raja Grafindo Persada, 2002), hlm. 27-28.

19 Murtadha Muthahhari, Perempuan \& Hijab, (Jakarta: PT. Lentera Basritama, 2002) cek.2, hlm. 
Adapaun penggunaaan hijab bagi perempuan adalah sebuah istilah baru yang bersifat relatif. Menurt istilah fuqaha zaman dahulu kata sitr-lah yang digunakan dengan makna hijab sekarang. Memang hijab sendiri sudah pernah meluas di sebagian negara zaman dahulu, seperti India, Iran dan Persi yang bertujuan membedakan perempuan dari kalangan ningrat dengan perempuan budak. Tetapi esensinya sama sekali berbeda dengan Islam. Maksud Hijab bagi perempuan dalam Islam adalah agar perempuan menutup tubuhnya ketika berbaur dengan laki-laki (yang bukan mahramnya), tidak mempertontonkan kecantikannya, dan tidak pula mengenakan perhiansan (secara berlebihlebihan). Bahkan belakang ini yang menjadi term di masyarakat kata hijab selalu mencerminkan pakaian yang serba tertutup atau menutup semua bagian tubuh perempuan kecuali seklias mata dan telapak tanganngya. ${ }^{20}$

Secara Secara historis, istilah hijab, jilbab atau purdah berevolusi secara bertahap, selama tiga abad pertama Islam, sampai pada puncaknya yaitu selama abad X dan XI M., dengan dukungan interpretasi kaum teolog dan fuqahâ pada masa khalifah 'Abbasiyah. Sejak itu pula hijab (purdah) menjadi bagian integral masyarakat dan kebudayaan kaum muslimin di abad pertengahan, sampai-sampai seorang perempuan non-muslimpun seakan-akan dipandang sebagai muslimah hanya karena mengenakan hijab atau purdah (cadar). ${ }^{21}$ Adapun mengutip dari Murthadha bahwa praktik pemakaian hijab atau jilbab dan alat tutup lainnya sudah ada sejak zaman dahulu, sebelum Islam itu ada. Jelasnya hijab sudah ada ditengah-tengah masyarakat sebelum Islam, diantaranya adalah penduduk Iran tempo dulu, kelompok-kelompok yahudi, bahkan sudah ada juga di India yang konon lebih keras dibanding aturan dalam syari'at Islam. Sedangkan pada masa arab Jahiliyah sendiri, belum mengenal hijab kecuali setelah munculnya Islam. ${ }^{22}$ Dalam perjalanan sejarahnya jelas bahwa sistem jilbab atau purdah (cadar), sudah ada jauh sebelum Islam itu lahir meski dengan cara dan tujuan yang berbeda.

58, atau lihat juga dalam Hijab: Gaya Hidup Wanita Islam, hlm. 11

20 Murtadha Muthahhari, Perempuan \& Hijab..., hlm. 59

21 Abdul Mustaqim, Tafsir..., hlm. 268

22 Murtadha Muthahhari, Perempuan \& Hijab..., hlm. 5 


\section{Telaah Praktik Hijabisasi Di Lingkungan UIN Sunan Kalijaga}

Di era modernisasi ini, masih ada mungkin banyak prilakuhijabisasi di Indonesia terlebih di lingkungan UIN Sunan Kalijaga (yang secara eksplisit sudah ada pernyataan larangan berpakaian serba tertutup seperti itu sekalipun), bahkan sudah menjadi suatu komunitas yang disebut (niqabis) ${ }^{23}$. Namun perlu kita garis bawahi secara historis praktik hijabisasi atau berjilbab (meski berbeda dengan sekarang) bukanlah suatu ajaran islam yang murni. Akan tetapi hal tersebut sudah ada sejak zaman sebelum datangnya Islam.

Selanjutnya Riffat Hassan mengemukakan bahwa:

"Munculnya konsep purdah bermula dari adaya sistem pembagian dua wilayah dalam masyarakat Islam: yakni wilayah privat (dalam rumah) dan wilayah umum (tempat kerja). Para perempuan pada umumnya berada di wilayah privat, sedangkan laki-laki berada di wilayah umum. Menurut asumsi umum umat Islam, selama masing-masing berada ditempatnya, maka semuanya akan beres dan aman. Dengan kata lain, kedua jenis kelamin itu harus dipisahkan dan pengaturan semacam ini dianggap paling tepat dan paling baik". ${ }^{24}$

Awal mulanya perempuan memakai purdah (cadar), sebagai atribut lain yang menutup wajahnya adalah ketika kondisi memaksa kaum perempuan untuk masuk wilayah umum, dikarenakan alasan ekonomi yang menuntutnya untuk bekerja atau alasan lainnya, maka perempuan harus diberi tutup (hijab) atau purdah (cadar). Dengan demikan keberadaanya seolah tidak ada, karena semuanya tertutup dan terlihat tanpa identitas. ${ }^{25}$

Kembali melihat redaksi larangan yang disampaikan oleh Warek III tentang "larangan berbusana ala kearab-araban di lingkungan UIN" ini menunjukan bahwa praktik busana tersebut hanyalah suatu tradisi dari satu etnografi atau sebut saja tradisi muslimah Arab. Sebagaimana pendapat jumhur Ulama bahwa

23 Data didapat melalui wawanara dengan salah satu responden (NR) yang terhimpun dalam komunitas niqabis di lingkungan UIN Sunan Kalijaga yang jumlah anggotanya saat ini sekitar 30 orang. Setiap hari jumat dikala sedang berlangsungnya ibadah shalat jum'at, mereka mengadakan kajian khusus yang semua anggotanya terdiri dari kalangan perempuan muslimah yang berbusana tertutup (sebagian besar memakai cadar).

24 Lihat Riffat Hasan, Women Religion and Sexuality, sebagaimana dikutip oleh Abdul Mustaqim dalam Epistemologi Tafsir Kontemporer, (Yogyakarta: Lkis, 2010), hlm. 269

25

Mustaqim, Epistemologi..., hlm. 
purdah/ niqab (cadar) bukanlah suatu bentuk ibadah melainkan hanya tradisi atau budaya. ${ }^{26}$ Maka dari sudut pandang sosial, adanya larangan berbusana hijabi, tidak lain untuk senantiasa memperlihatan identitasnya sendiri sebagai warga Indonesia, selain sebagai upaya preventif dari maraknya gerakan radikal yang secara simbolik berbusana serba tertutup. Oleh karena itu, jika dilihat dari aspek sosial busana tersebut tidaklah sama dengan praktik berbusana atau cara menutup aurat yang ada di masyarakat kita. Secara geografis dan etnis, Indonesia berbeda dengan Negeri padang pasir tersebut, maka cara memahami dan mengekspresikan nilai-nilai keislamannya pun berbeda. Sehingga corak berbusana yang ada di Indonesia mempengaruhi nilai-nilai Agama (Islam) dalam hal berbusana. Dari sini, kita dapat melihat bahwa posisi Agama dalam masalah berbusana adalah sebagai dependent variable. Artinya Agama dipengaruhi oleh budaya daerah tertentu.

Kaitannya dengan wahyu Allah (QS. Al-Ahzab [33]: 59), tentang busana perempuan atau penutup aurat, maka tidak hilang dari esensinya. Karena dalam menutup aurat bukanlah busana tertutup atau hijabisasi yang menjadi ajaran Islam yang dikehendaki. Sebagaimana penafsiran Fazlur Rahman (yang senan tiasa mengkaji setiap masalah dengan melihat realita historis-empiris dan pandangan al-Quran), terkait dengan pakaian perempuan, menyatakan bahwa konsep jilbab pada intinya tidak harus menutup seluruh tubuh seperti pemahaman para muffasir klasik, melainkan busana yang dapat menutup tubuhnya menurut rasa kepantasan. Dimana dalam hal ini Fazlur Rahman lebih cenderung melihat dimensi ldeal moralnya dari pada legal formalnya. Adapun dimensi ideal moralnya adalah bahwa seorang harus bersikap sopan, indah, bersahaja dan memakai pakaian sesuai dengan standar kesopanan meski tidak harus menutup seluruh tubuhnya. ${ }^{27}$ Hal demikian menurut penulis yang sependapat dengan Mustaqim lebih baik dari pada berbusana muslimah tapi serba ketat terlihat lekukan tubuhnya layaknya tidak memakai pakaian.

Di sisi lain praktik hijabisasi (bercadar dan berjilbab), bukanlah tradisi kita, melainkan tradisi muslimah Arab pada umumnya. Dimana dari letak geografis Arab merupakan daerah gurun pasir dan gersang sehingga secara berbusana memerlukan busana yang tertutup sehingga dapat menjaganya dari gangguan

\footnotetext{
26 Mahmud Hamdi Zaqrûq, an-Niqâb 'Âdatun Laisa 'Îbâdatun: ar-Ra'yu asy-Syar'î fi an-Niqâb biAqlâmi Kibari al-Ulama, (Mesir: Dârul Kutub al-Misyriyyah, 2008), hlm. 14

27 Lihat Abdul Mustaqim, Epistemologi..., hlm. 272
} 
yang bersifat alamiyah tersebut, disamping guna menjaganya dari gangguan secara sosial. Sedangkan Indonesia dengan Negara tropisnya tidak menuntut untuk berbusana seperti layaknya orang Arab disana. Maka menrurut hemat penulis cukup cara berjilbab dengan tradisi dan corak Indonesia yang biasabiasa saja dan penuh variasi (trend hijaber), asal tidak sampai melebih-lebihkan. Karena cara tersebut juga dirasa tidak lepas dari fungsi jilbab itu sendiri yaitu menjaga dari gangguan alamiyah maupun yang secara sosial. ${ }^{28}$

Adapun dilihat dari dimensi sosialnya, mereka yang berbusana hijabi serba tertutup (jilbab dan cadar) dilingkungan UIN dengan corak warna yang identik juga cenderung tertutup baik interaksi dengan perempuan lainnya terlebih dengan laki-laki. Maka terlihat jelas bahwa praktik hijabisasi sebagai cara berbusana yang menutupi seluruh tubuhnya, tidak hanya dalam konteks dekorasi atau 'penampilan' ouner beauty, akan tetapi dalam ranah bersosialpun menjadi lebih tertutup artinya enggan untuk lebih terbuka dalam bersosial meski mereka merasa dapat respon positif dari beberapa kalangan eksternal. ${ }^{29}$ Disamping itu, yang menjadi alasan mereka berbusana seperti itu tidak lain atas dasar keinginanya sendiri, dengan alasan bahwa berbusana seperti itu dirinya lebih aman, terjaga dan terlindungi (sebagaimana sejarahnya, lihat Muthahhari: 1994), baik dari ganguan alamiyah, seperti angin, panas, debu dan lainya ataupun dari gangguan yang sifatnya sosial, seperti diremehkan dan pelcehan. Selain itu mereka merasa percaya diri dan lebih nyaman dibanding berbusana dengan pakain yang kecil dan ketat dimana hal ini menjadi faktor internal. Sedangkan dari faktor eksternalnya ada beberapa varian alasan, salah satunya adalah adanya dukungan dari orang tua dan beberapa teman yang sudah berbusana hijabi lebih dahulu, ada pula yang beranggapan untuk mengikuti sunnah Nabi. ${ }^{30}$

\footnotetext{
28 Abdul Mustaqim, Epistemologi..., hlm. 277.

29 Sebagaimana pengakuan dari responden, bahwa mereka menyadari akan adanya perbedaan respon sosial dari teman-temannya dan pandangan orang lain pada umumya, yangmana mereka tidak bermaksud untuk terlihat tertutup dalam bersosialisasi, tetapi mereka sendiri yang merasa minder dengan sikap dan pandangan umum dengan namun pada akhirnya mereka acuh dengan sikap dan keadaan seperti itu. Berdasarkan wawancara dengan (NR), pada hari sabtu $30 / 12 / 2017$

30 Wawancara dengan (QF), pada hari sabtu 30/12/2017
} 


\section{KESIMPULAN}

Berdasarkan telaah praktik hijabisasi di lingkungan UIN Sunan Kalijaga dalam perspektif sosiologi, pertama tidak benar jika hijab adalah monopoli Islam. Karena realitanya praktik berhijab dan berjilbab sudah ada dan dipraktikkan oleh masyarakat terdahulu sebelum datangnya Islam bahkan menjadi budaya dan stratifikasi kaum perempuan pada masa Persi. Kedua praktik hijabisasi pada zaman sekarang merupakan tradisi masyarakat muslim Arab dan bukan ajaran Islam yang murni. Sehingga berbeda dengan praktik hijabisasi yang ada di Indonesia yang tidak serba tertutup, tetapi memiliki corak sendiri yang varian. Hal ini dipengaruhi banyak faktor, seperti letak geografis dan tradisi.

Kemudian berdasarkan konsep sosiologi dalam permasalah hijabisasi ini, posisi Agama adalah sebagai dependent variabel yang dipengaruhi oleh unsur lain yaitu tradisi masyarakat itu sendiri. Hijabisasi yang serba tertutup merupakan tradisi muslim Arab, maka tidak salah ketika hijabisasi tidak dipraktikan di Indonesia, bahkan sampai adanya larangan di lingkungan UIN Sunan Kalijaga. Hal demikian merupakan salah satu upaya prevenif karena banyak stigma negatif terhadap praktik hijabisasi yang berkembang seperti saat ini, seperti adanya indikasi gerakan radikalisme.

Begitulah perkataan Wakil Rektor (WR) III bahwa kita ini Indonesia, dan perlu kembali ke konteks Islam wasatiyyah (Islam moderat), dengan praktik hijabisasi atau bercadar itu membuat orang secara umum tidak mengenali kita itu siapa dan dari mana. mengingatkan bahwa baik berpakaian Islami maupun berpakaian Indonesia itu yang tidak boleh adalah truth claim (klaim yang paling benar). Dari sini terlihat bahwa dengan adanya praktik hijabisasi dikhawatirkan adanya indikasi truth claim seperti itu.

Kemudian jika melihat standar berpakaian yang dianjurkan Rosulullah sebagaimana yang dijelaskan Imam Muhammad Ali As-Shobuni, yaitu; menutup aurat, tidak transparan dan tidak ketat. Mengutip Rawa'iul Bayan, Ali As-Shobuni menyebut adanya fenomema kasiyatun 'ariyatun, yang artinya berpakaian tapi telanjang, karena ketat dan transparan. Dilingkungan UIN sendiri sampai saat ini, khususnya penulis pribadi masih menemukan beberapa mahasiswa yang berbusana ala Arab. Adapun yang menjadi alasan mereka berbusana seperti itu tidak lain atas dasar keinginanya sendiri. mereka beranggapan dengan berbusana seperti itu, dirinya lebih aman, terjaga dan terlindungi baik dari 
ganguan alamiyah, seperti angin, panas, debu dan lainya ataupun dari gangguan yang sifatnya sosial, seperti diremehkan dan pelcehan. Selain itu mereka merasa percaya diri dan lebih nyaman dibanding berbusana dengan pakain yang kecil dan ketat dimana hal ini menjadi faktor internal. Sedangkan dari faktor eksternalnya ada beberapa varian alasan, salah satunya adalah adanya dukungan dari orang tua dan beberapa teman yang sudah berbusana hijabi lebih dahulu.

\section{DAFTAR PUSTAKA}

Hamdi Zaqruq, Mahmud, 2008, an-Niqâb 'Âdatun Laisa 'Îbâdatun: ar-Ra'yu asy-Syar'î fi an-Niqâb bi-Aqlâmi Kibari al-Ulama, (Mesir: Dârul Kutub alMisyriyyah)

Shahrur, Muhammad, 2000, Nahwu Usul Jadidah Li al-Fiqih al-Islami: Fiqih alMar'ah,al-Wasiat, al-Irts, al-Qiwâmah, at-Ta'addiyah, al-Washiyyah, alLibâs, (Damaskus: al-Ahali li ath-Thiba'ah wa an-Nasyr wa at-Tauzi')

Haryanto, Sindung., 2016, Sosiologi Agama: Dari Klasik Hingga Postmodern, (Yogyakarta: Ar-Ruzz Media).

Mudzhar, Atho., 2011, Pendekatan Studi Islam: Dalam teori dan Praktik, (Yogyakarta: Pustaka Pelajar).

Mustaqim, Abdul, 2010, Epistemologi Tafsir Kontemprer, (Yogyakarta: PT. Lkis). Muthahhari, Murtadha, 1994, Gaya Hidup Wanita Islam, cet. V (Bandung: Mizan). 2002, Perempuan \& Hijab, (Jakarta: PT. Lentera Basritama,).

Nata, Abuddin., 2002, Metodelogi Studi Islam, (Jakarta : RajaGrafindo Persada).

Nottingham, Elizabeth K., 2002, Agama dan Masyarakat: Suatu Pengantar Sosiologi Agama, Cet.8 (Jakarta: PT. Raja Grafindo Persada).

Shahrur, Muhammad., 2010, Metodologi Fiqih Islam Kontemporer, (Yogyakarta: eLSAQ Press).

Thawilah, Abdul Wahhab Abdussalam,2006, Panduan Berbusana Islami: Berpenampilan Sesuai Tuntunan al-Qur'ân dan as-Sunnah, (Kairo: Dar asSalam)

Tim Penyusun Kamus Besar Bahasa Indonesia, 1989, Kamus Besar Bahasa Indonesia, cet.2, (Jakarta: Balai pustaka). 